\title{
THE IMPACT OF A COMMUNE'S PLANNING TACTICS ON THE LANDSCAPE OF SUBURBAN AREAS
}

\author{
Elzbieta Zysk, PhD \\ Faculty of Geodesy, Geospatial and Civil Engineering \\ University of Warmia and Mazury in Olsztyn \\ e-mail:elzbieta.zysk@uwm.edu.pl
}

\author{
Alina Źrobek-Różańska, PhD \\ The Faculty of Economics \\ University of Warmia and Mazury in Olsztyn \\ e-mail:alina.zrobek@uwm.edu.pl
}

\begin{abstract}
The article aims to present selected transformations of landscape that follow changes in land use designated by suburban municipalities. Currently, under the pressure of suburbanization, suburban rural municipalities are gradually being transformed into urban-style residential units. Modern and dense residential constructions shape the local landscape by introducing irreversible changes. Directing this process seems to be an important aim for local authorities, which should responsibly apply planning tools and carry out policies which minimize negative changes to the landscape and promote spatial order. In this respect, the paper presents the relationship between the spatial strategy adopted by a municipality and the transformations in the landscape for two selected municipalities: Dywity and Barczewo.
\end{abstract}

Key words: suburban areas, landscape transformation.

JEL Classification: R58.

Citation: Zysk E., Źrobek-Różańska A., 2016, The Impact of a Commune's Planning Tactics on the Landscape of Suburban Areas, Real Estate Management and Valuation, vol. 24, no. 4, pp. 59-69.

DOI: $10.1515 /$ remav-2016-0030

\section{Introduction}

The development of various urban functions requires space that more and more frequently extends beyond the administrative borders of cities. In effect, the phenomenon of the "urban sprawl" of cities onto adjoining areas has been observed since the last century. The transfer of urban functions, characterized by a significant density of development onto rural areas, causes irreversible changes in the landscape. Rural areas, which have been used mainly for agricultural purposes for a number of years, lose their original functions (GORDON, RICHARDSON 1997; NELSON 1999; KOOMEN 2007). A change in the traditional intended use of villages takes place, along with the distortion of the landscape by the introduction of intense development characterized by a style and structure differing from the buildings already in use. Changes in the landscape caused by the introduction of new, different and architecturally foreign elements greatly depends on the manner of conduct and the monitoring of the spatial policy of communes and planning instruments used.

This publication is aimed at presenting the terms related to landscape within legal provisions, the verification of planning instruments in a selected rural commune as well as an urban and rural 
commune, and a description of sample changes in the urban and architectural landscape. The studies were conducted on the basis of data from the Central Statistical Office, the development strategy of Barczewo and Dywity communes, local spatial development plans and decisions on the conditions of building and site development.

\section{Landscape as a Term in Legal Provisions}

The European Landscape Convention defines the landscape as a part of the land, as perceived by people, which evolves through time as a result of being acted upon by natural forces and human beings. The landscape is shaped by a relevant policy which entails the issue, by competent public authorities, of general principles, strategies and guidelines that allow for undertaking special measures aimed at landscape protection, management and planning. By assumption, the landscape should be protected, and thus actions should be aimed at the preservation or maintenance of important or characteristic features of the landscape. In relation to this, landscape management means a set of actions undertaken to protect the landscape, taking into account durable and sustainable development. Such activities should be aimed at ensuring regular sustenance of the landscape by managing and harmonizing its changes resulting from social, economic and environmental processes. Therefore, people responsible for landscape planning should undertake efficient prospective activities aimed at the extension, recovery or establishment of the landscape.

The presented guidelines of the European Landscape Convention are a part of the activities taken by Polish state authorities in the area of landscape protection. In 2015, the President of the Republic of Poland signed an Act on Amendments in Certain Acts Related to Reinforcing Landscape Protection Tools of April 24, 2015 (Journal of Laws of 2015, item 774, 1688), which indicates landscape protection tools. This legal act also includes definitions of landscape. One of the key legal acts which has a significant impact on the shaping of space, its management, and the shape of the landscape, is the Spatial Planning and Management Act of March 27, 2003. In this act, landscape is understood as a space perceived by people, containing natural elements or products of civilization, shaped as a result of the operation of natural factors or human activity. What is more, the term priority landscape was also defined, i.e. landscape that is particularly valuable for the society on account of its natural, cultural, historical, architectural, urban, rural or esthetic and visual values and, as such, requires observance or specification of the principles and conditions for its shaping. In the Environmental Protection Law of April 27, 2001 (Journal of Laws of 2013, item 1232), a uniform definition of landscape is missing. Nevertheless, it may be determined by recreating the definition of the environment, which is understood as the entirety of natural elements, including elements transformed as a result of human activity, in particular the surface of land, minerals, water, air, landscape, climate and other elements of biological diversity, as well as the mutual impact of these elements on each other. The Monument Conservation and Protection Act (Journal of Laws of 2014, item 1446, of 2015 item 397,774 ) contains a definition of cultural landscape as a space, perceived by people, containing natural elements and products of civilization, shaped historically as a result of the operation of natural factors and human activity. On the other hand, the Nature Conservation Act (Journal of Laws of 2013, 627 as amended) refers to the definition of landscape included in two of the above-mentioned documents, i.e. the Spatial Planning and Management Act, and the Monument Conservation and Protection Act. An important provision is included in Art. 5.23, referring to landscape values. In line with the adopted definition, a landscape value constitutes a natural, cultural, historical, esthetic or visual value of an area and the land relief, products and elements of nature related to them, as well as elements of civilization, shaped by the forces of nature or by human activity.

It may be concluded from the above-listed legal acts that, in spite of the common awareness of the necessity of landscape protection, the Polish legal system still lacks a clear definition of this term. The definition is modified depending on the formal requirements set out in a given legal act. However, the landscape is inseparably linked to a specific location, regardless of the definition used. It depends on all the elements comprising it, both the natural environment and the environment created by man, e.g. the type of residential development. In a period of intense urban sprawl onto the surrounding rural areas, thus far characterized by relatively low population density and development, the last component exerts a great impact on changes in the landscape. Local government authorities are responsible for the protection of landscape values, including the proper distribution of consistent residential development. The instruments they can use include local spatial development plans, land 
use plans and decisions on the conditions of building and decisions on the conditions of building and site development (zoning permits).

\section{Characteristics of the Study Object}

The current processes that take place in rural areas refer to transformations in all aspects: of landscape, of space, of the natural environment, and of the infrastructure (MCDONAGH 2007). The most visible are spatial changes resulting from urban sprawl, i.e. the ones that take place in rural areas adjoining large urban centers. The process of urban sprawl onto suburban rural areas is perceptible throughout Poland, including Warmia and Mazury Province (ŹRÓBEK-RÓŻAŃSKA and ZYSK 2015). Studies by A. Wolny and R. Źróbek (2012) show that the city of Olsztyn has a significant impact on changes in the functional structure (intended use of areas) and utility structure (intensity of area use) in the adjoining communes. Migration processes from Olsztyn to the suburban communes were examined by ŹRÓBEKRÓŻAŃSKA and ZYSK (2015). According to the studies, the residential function continues to develop in all communes adjoining the city. Two suburban communes (Dywity and Barczewo) were selected for detailed analysis.

In the Dywity rural commune, the majority of used areas are of a forest and agricultural character with well-developed tourism and recreational facilities. Farmland takes up half of the commune's surface area; another type of land is forest land, which makes up $23 \%$ of the surface. A part of the commune area lies within the borders of the landscape protection area of the valley of the middle Łyna River. The commune adjoins Lake Wadacg. The area of the commune is diversified with respect to elevation, and is characterized by a great number of mid-field waterholes and marshy areas. On the other hand, the town and the urban and rural commune of Barczewo occupy an area of approx. 32,000 hectares, out of which approx. 10,000 hectares are forests. This is a typically agricultural commune. The area of the commune is undulating. Approx. 5\% of the commune's surface area is comprised of lakes. Two rivers (the Kiermas and the Pisa) cross the commune. Forests make up approx. $30 \%$ of the surface area (www.barczewo.bip.net.pl/?c=87).

One of the basic indices that show spatial assignment is the population density index. In 2014, the population density index per $1 \mathrm{~km}^{2}$ in Dywity Commune amounted to 69 people per $1 \mathrm{~km}^{2}$, whereas in Barczewo Commune, it was 55 people per $1 \mathrm{~km}^{2}$, and was, in both cases, higher than the average value for Olsztyn County (43 people per $1 \mathrm{~km}^{2}$ ). The analysis of age structure shows that, in 2014 , the largest social group in both communes was comprised of people at an economically productive (working) age (Table No. 1).

Table 1

Age structure of the population in the examined communes in years 2011 and 2014

\begin{tabular}{cccc}
\hline Communes & $\begin{array}{c}\text { Population in pre- } \\
\text { productive age }\end{array}$ & $\begin{array}{c}\text { Population in } \\
\text { working age }\end{array}$ & $\begin{array}{c}\text { Population } \\
\text { in retirement age }\end{array}$ \\
\hline Dywity & 2313 & 7353 & 1431 \\
\hline Barczewo & 3421 & 11437 & 2607 \\
\hline
\end{tabular}

Source: Own study based on CSO data.

In communes located within the impact zone of the city, one of the main factors influencing changes in the size of the population and the age structure is the phenomenon of migration. In the examined communes, the average migration balance in the years 2011 and 2014 had a positive value, greatly exceeding the birth rate value (Table 2).

Table 2

Changes in the population numbers in the examined communes in the years 2011 and 2014

\begin{tabular}{llrl}
\hline Communes & $\begin{array}{l}\text { Increase in } \\
\text { population }\end{array}$ & the $\begin{array}{l}\text { Natural increase per } \\
1,000 \text { inhabitants }\end{array}$ & $\begin{array}{l}\text { MIgration balance per } \\
1,000 \text { inhabitants }\end{array}$ \\
\hline Barczewo & 104 & 4.0 & 8.1 \\
\hline Dywity & 152 & 3.3 & 13.6 \\
\hline
\end{tabular}

Source: Own study based on CSO data.

An important aspect of the development of functions other than agricultural in rural areas includes the legal, economic and social determinants for undertaking economic activity. In Barczewo and 
Dywity communes, these determinants are positive, as both communes are characterized by a relatively small number of entities pursuing agricultural activity. In 2014, most entities in Dywity Commune were conducting business in the industrial sector, while in Barczewo Commune - in the construction sector (Table 3). Therefore, it may be concluded that both communes have already lost their traditional agricultural and rural character.

Table 3

Number of national economy entities divided into sectors in the Dywity and Barczewo communes in 2014

\begin{tabular}{|l|c|c|}
\hline Economy Entities & Dywity & Barczewo \\
\hline Number of national economy entities divided into sectors: & 1412 & 1448 \\
\hline Agricultural sector & 30 & 47 \\
\hline Industrial sector & 178 & 144 \\
\hline Construction sector & 172 & 212 \\
\hline
\end{tabular}

Source: Own study based on CSO data.

The desired further direction of commune development is specified in the commune development strategies. It may be concluded from the document entitled "Development Strategy of Dywity Commune Until 2020" that the commune authorities are counting on further development of the residential function, expecting an inflow of new residents (on account of the growing demand for living outside of cities), investors (on account of the possibility of locating enterprises in the vicinity of a large municipal center), as well as tourists (mainly Olsztyn residents) using the areas adjoining the city for recreational and leisure purposes. According to the premises of the development strategy of Barczewo Commune for the years 2015 - 2025, the commune authorities support recreational investments, in particular leading to the construction of year-round tourist facilities of high standard. Furthermore, the authorities see a possibility for the development of a spa on the basis of conducive climate conditions, the development of entrepreneurship relying on the Special Economic Zone in Dobre Miasto, as well as the development of assisting functions with respect to the city of Olsztyn. Neither of the examined communes assumes the domination of clearly rural functions.

\section{Examination of Planning Instruments in Selected Communes}

Communes adjoining large municipal centers, subject to the pressure of the nearby city, have to be guided by legal provisions in the area of spatial management in their spatial policy. In modern times, the determination of functions other than agricultural in rural areas is a practice commonly applied by the authorities of local administration. According to statistical data, the surface of developed and urbanized land is systematically growing in Poland, with a simultaneous drop in the surface of land used for agriculture (www.stat.gov.pl). This phenomenon is consistent with the situation on the real property market.

According to the data of the Central Statistical Office (2013), most sale and purchase transactions in 2012 referred to landed properties $(43.8 \%)$, with transactions in properties located outside of cities being dominant $(80.4 \%)$. Proper policy of the commune with respect to land, including land with changing owners, should be used to coordinate, supervise and manage the space in a given area. This is implemented primarily by local plans, land use plans and decisions on the conditions of building and site development. However, an efficient control tool with respect to the observance of such provisions is missing. The completion of a construction is notified to the county starosty, which only controls the documents and not the actual condition of a building.

The analysis of planning instruments started with the verification of local spatial development plans (LSDP). As of December 31, 2015, 58 resolutions were adopted on the local plan in Dywity Commune, with 24 resolutions in Barczewo Commune. In the area of Dywity Commune, the average surface of a local spatial development plan amounted to 78.4 hectares. In the majority of local spatial development plans (65.5\%), single family residential functions and residential and service functions dominated. In 2009, spatial development plans were published for a part of Bukwałd and Brąswałd villages in order to protect the historical development of Warmia villages. So far, these are the only studies of this type regarding the suburban area of Olsztyn. What is more, two spatial development plans were also prepared with the aim of protecting areas of valuable nature, i.e. the ecological corridor of the Łyna River (2006) and the polder in Różnowo (2009) (SOBOTKA 2014). 
Figure 1 presents the local spatial development plan for the village of Myki. This land was used for agricultural purposes, yet on account of its attractive location in the vicinity of Lake Wadąg, residential development became a new function assigned with respect to the development of this area. In this area, plots have regular shapes and are distributed in an orderly manner. The description is supplemented by Fig. 2, an orthophotomap of the area.

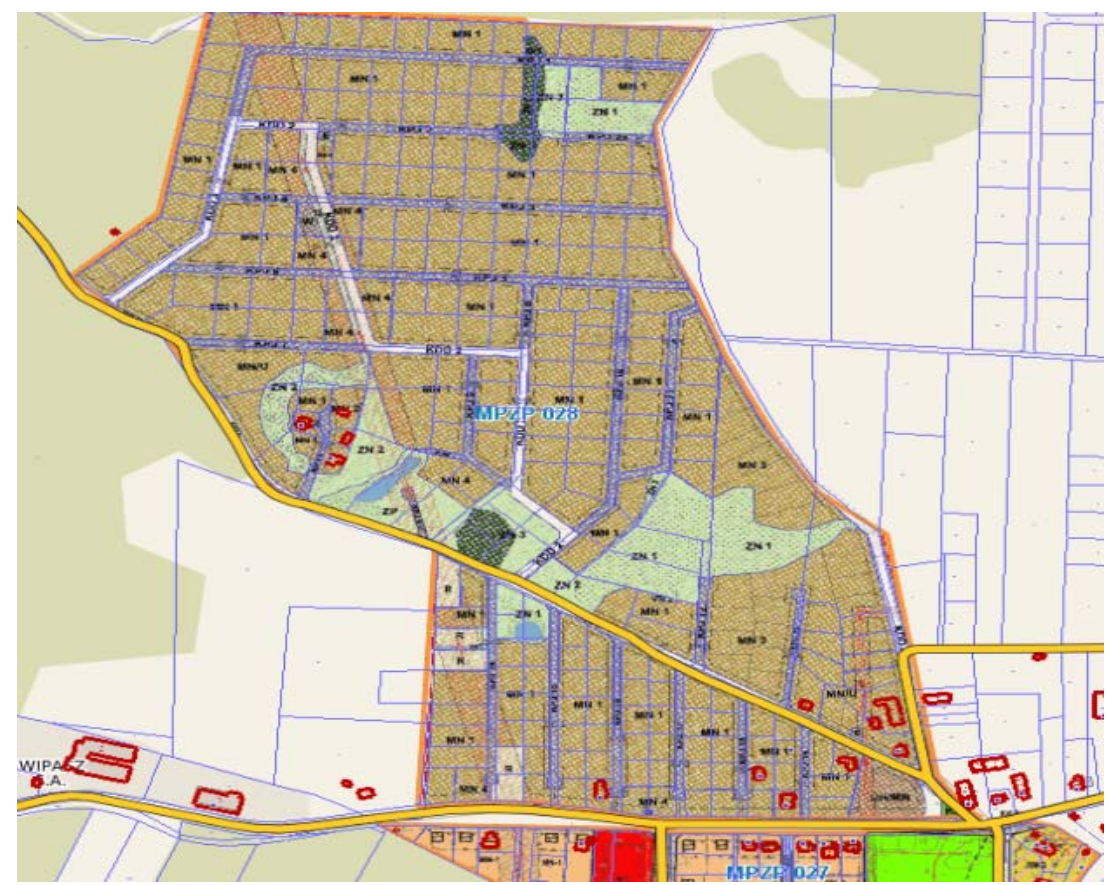

Fig. 1. Local spatial development plan for the village of Myki (Dywity). Source: http://dywity.emapa.net/

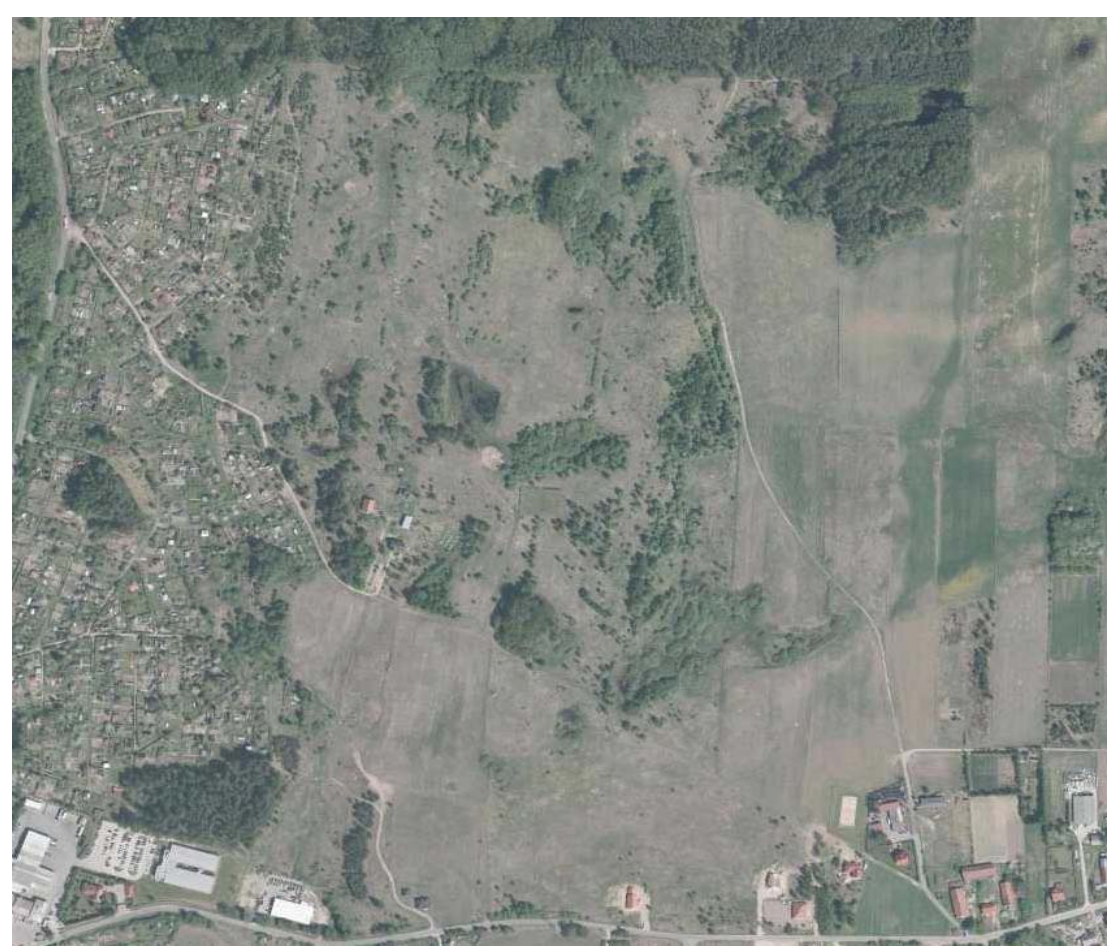

Fig. 2. Orthophotomap of the area of Myki (Dywity). Source:

http:/ / mapy.geoportal.gov.pl/imap/?gpmap=gp0\&actions=acShowWgButtonPanel_kraj_ORTO

In the area of Barczewo, the largest surface encompassed by local spatial development plans referred to the villages of Łęgajny and Wójtowo. The direct vicinity of the city of Olsztyn sparked 
great interest in residential properties. The commune authorities in Barczewo, wishing to procure investors, designated new areas for residential development. Areas surrounded by greenery and in the direct vicinity of reservoirs were divided into plots intended for residential development. The designation of residential developments in the indicated area cannot be considered an example of a responsible spatial policy which takes into account spatial order and sustainable development. These areas are not provided with access roads or technical infrastructure utilities (Fig. 3 and Fig. 4).

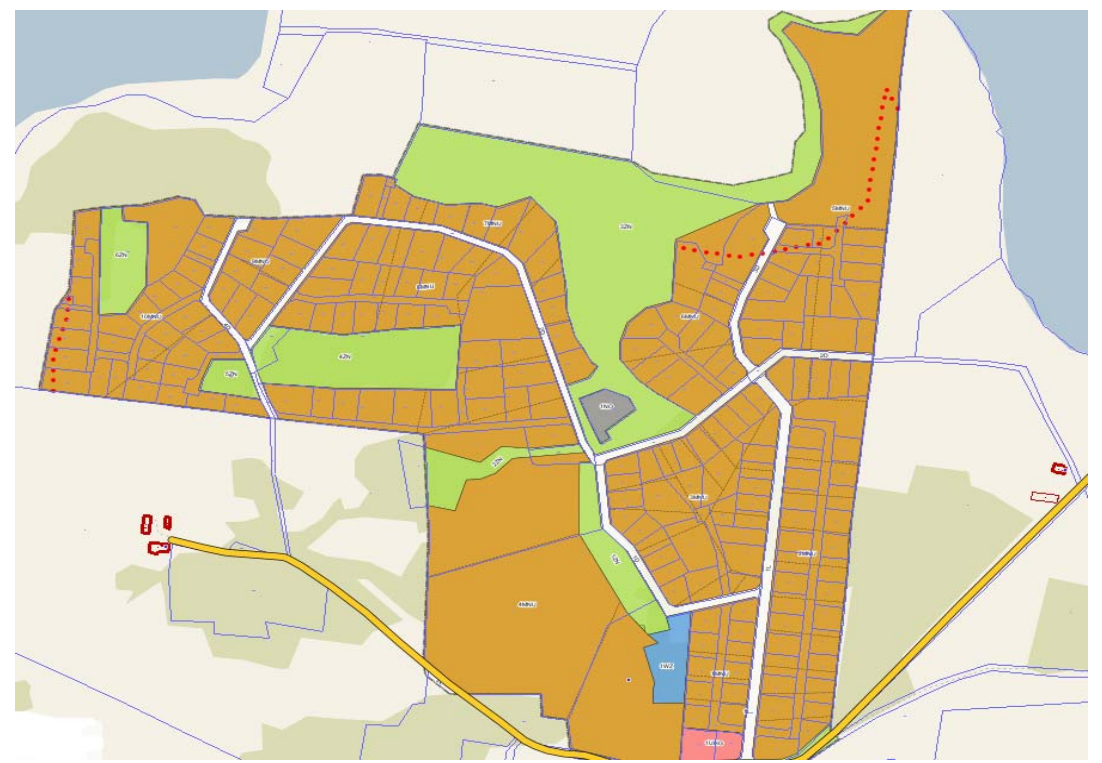

Fig. 3. Local spatial development plan for the village of Barczewo (Kolonia Mokiny). Source: http://barczewo.e-mapa.net/

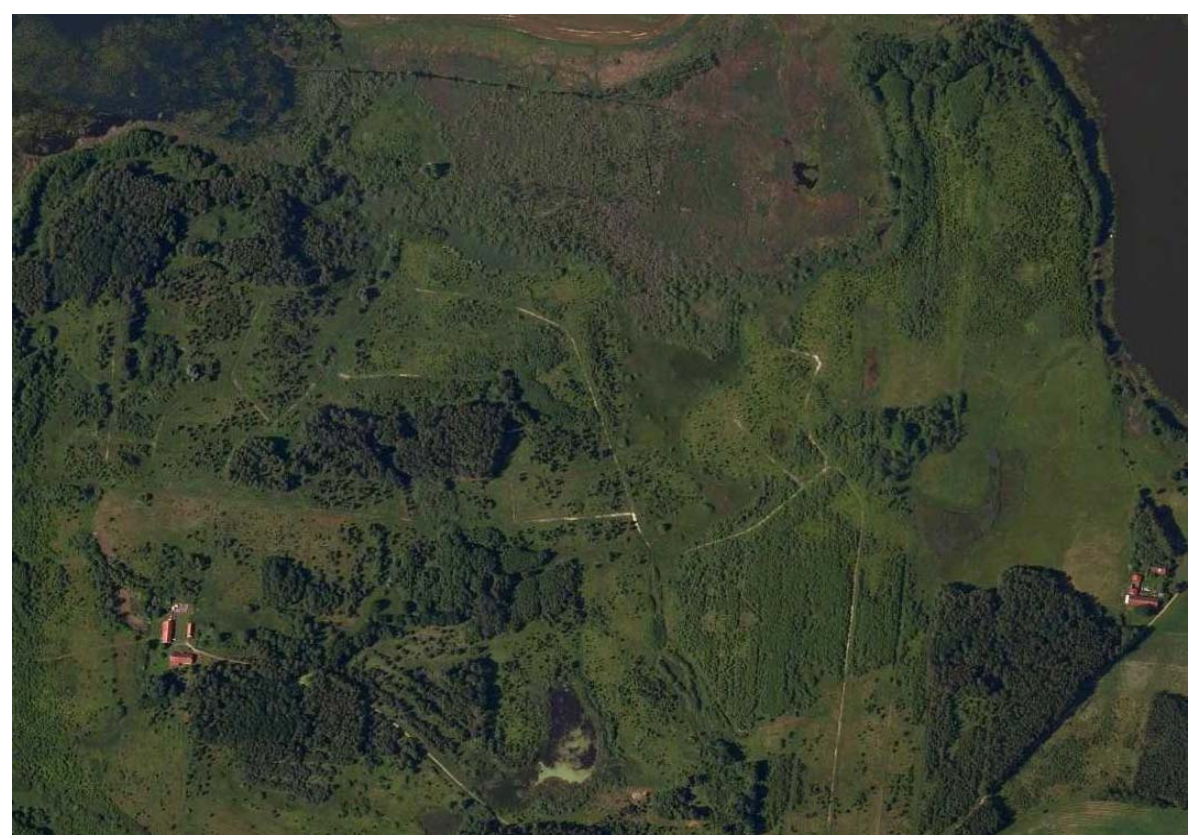

Fig. 4. The orthophotomap of the area Barczewo (Kolonia Mokiny).

Source:

http://mapy.geoportal.gov.pl/imap/?gpmap=gp0\&actions=acShowWgButtonPanel_kraj_ORTO.

The above presentations of local plans in the Dywity and Barczewo communes show that the communes respond to the needs of new residents and designate areas for residential development. Fig. 5 shows the distribution of plans in the individual communes. It follows clearly from the photos that most plans were located in villages which had good transport connections with the city of Olsztyn.

The next study stage referred to the analysis of issued decisions on the conditions of building and 
site development. The decision on the conditions of building and site development is an administrative decision that indicates the conditions of development for an area for which no local spatial development plan has been adopted. The conditions that should be fulfilled to enable the issue of a decision on the conditions of building and site development are specified in Art. 61.1 of the Spatial Planning and Management Act.

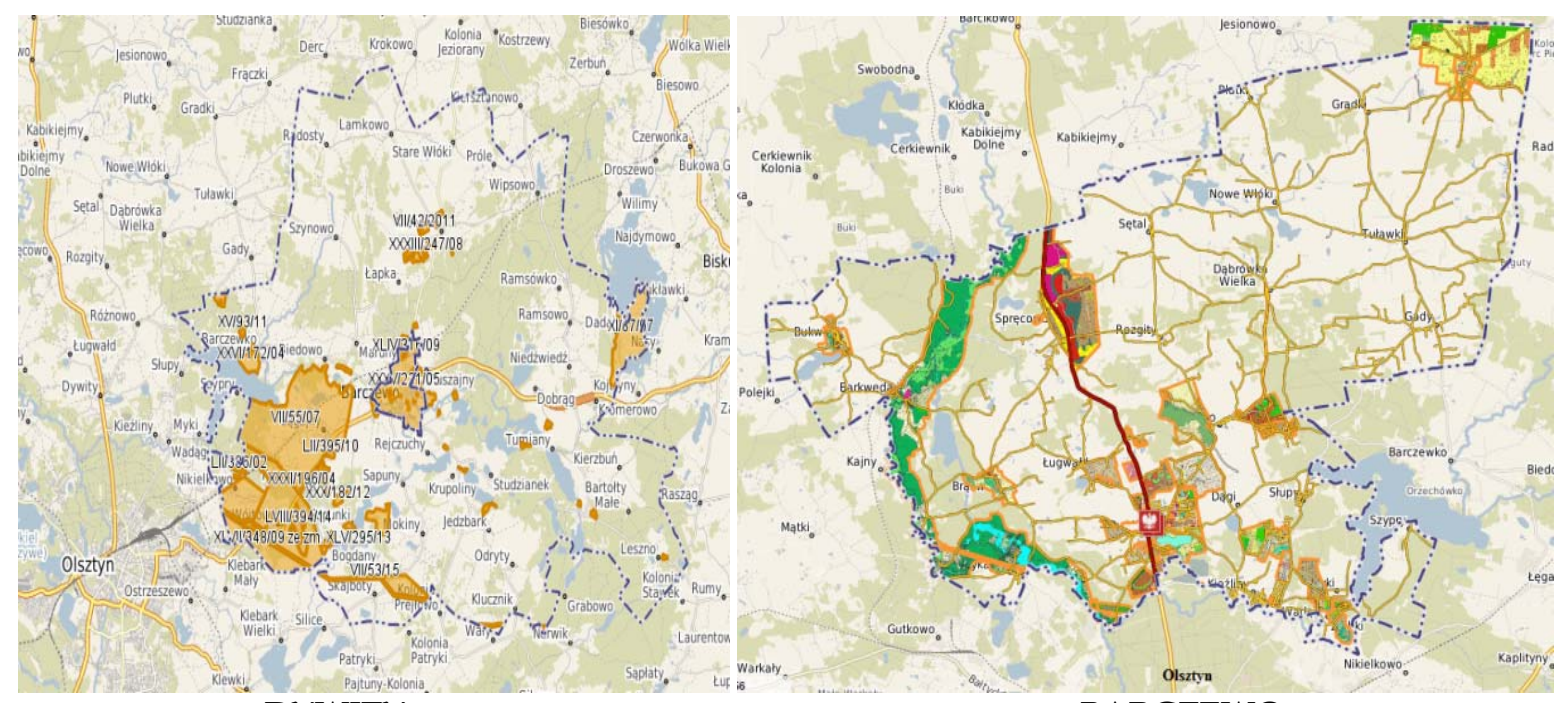

DYWITY

BARCZEWO

Fig. 5. Arrangement of local development plans in the municipalities of Dywity and Barczewo relative to the location of Olsztyn. Source: http:/ / dywity.e-mapa.net/; http://barczewo.e-mapa.net/

The decisions on the conditions of building and site development procured from the commune offices in Dywity and Barczewo refer to the years 2009 - 2013. The average annual number of permissions issued in this period in Barczewo amounts to 150, for Dywity Commune - 165. The permissions were also verified with respect to their issue for a specific investment aim. Most permissions were for residential development. It is possible to observe a significant drop in the number of permissions issued with respect to residential development in Barczewo. In 2010, the number of permissions referring to residential development amounted to 145, whereas in 2013, the number dropped to 35. A decreasing tendency was also observed in Dywity Commune, yet the decrease was not so significant (Fig. 6).

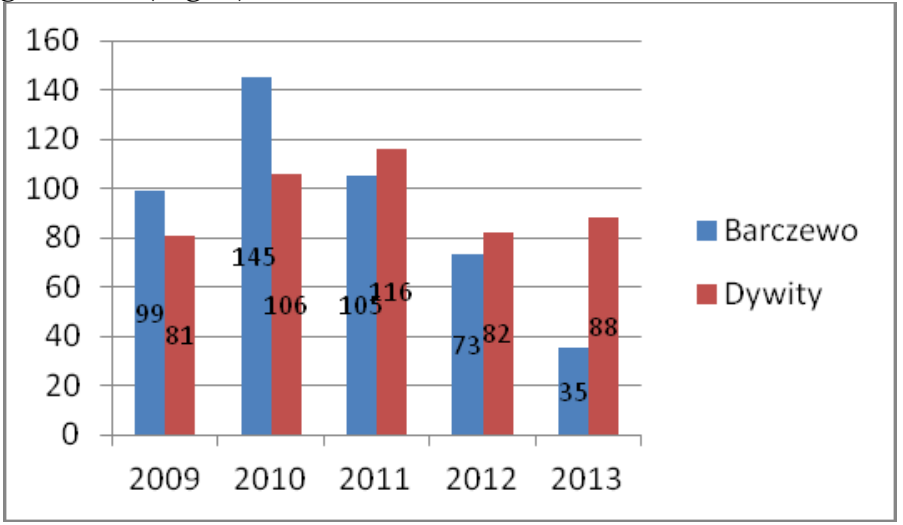

Fig. 6. Number of permissions issued with respect to residential development in Dywity and Barczewo. Source: Own elaboration based on data from the municipal office in Barczewo and Dywity.

The examined communes of Dywity and Barczewo follow the tendency of spatial and land use changes that could be observed over the last several years in the areas of rural communes in Poland (Zysk E. 2013). The presented planning instruments in the Dywity and Barczewo communes indicate a common dependency. The communes primarily take advantage to their location in the vicinity of the city of Olsztyn.

The distribution of local spatial management plans in communes confirms this situation. The 
spatial policy of communes indicates a dependency between the area for which a local plan was adopted and its location in relation to the urban center. The majority of plans in the Dywity and Barczewo communes were adopted in villages that had good transport connections and were located close to Olsztyn. An analogous situation takes place with respect to decisions on the conditions of building and site development. Most permissions in the years 2009 - 2013 were issued in Dywity, Kieźliny and Barczewko. It may be concluded that the commune authorities are trying to meet the demand for undeveloped land properties, attempting to follow a spatial policy that promotes the development of residential functions in what had previously been agricultural areas. However, being guided by economic motives, they do not always take into account the principles of natural environment protection (Mokiny settlement in Barczewo Commune).

\section{Changes in Urban and Architectural Landscape}

Urban development, often sprawling in a chaotic, random and inconsistent manner, devours areas with high natural, cultural and landscape values, thereby causing irreversible changes in the space. The examined communes of Dywity and Barczewo constitute an interesting example of the impact of residential investments promoted by the local policy on the landscape of suburban rural areas. Nevertheless, this is not always a responsible course of action. The transformation of agricultural and forest areas into residential zones entails a number of liabilities. This refers to the necessity of providing the area with technical infrastructure utilities and the construction of roads within the new housing estates. Communes usually do not possess sufficient funds, and, therefore, some of these costs are transferred onto the new owners of properties (ZYSK 2014).

The absence of an efficient system of enforcing the provisions of spatial development plans has caused the emergence of buildings with random shapes and colors (Fig. 7 and 8). This can also be observed in both Dywity (Różnowo village) as well as Barczewo (Wójtowo village) communes.

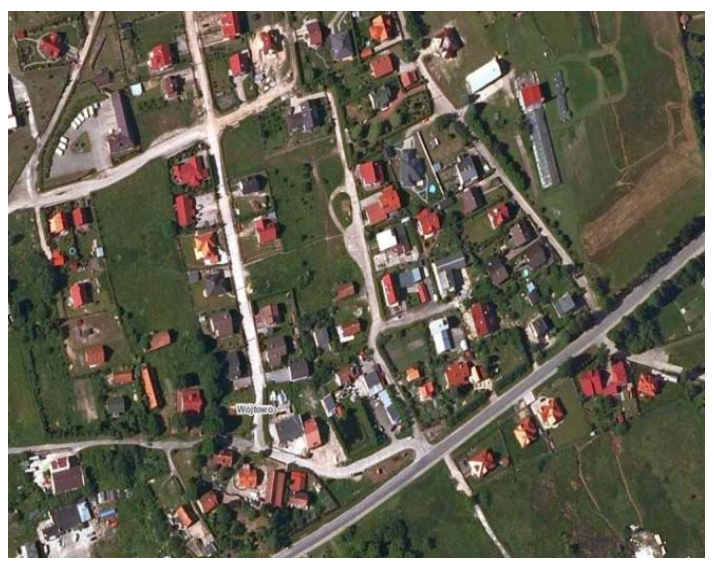

Fig. 7. Examples of buildings in Barczewo Commune (Wójtowo).

Source:http:/ / mapy.geoportal.gov.pl/imap/?gpmap=gp0\&actions=acShowWgButtonPanel_kraj_OR

$\mathrm{TO}$

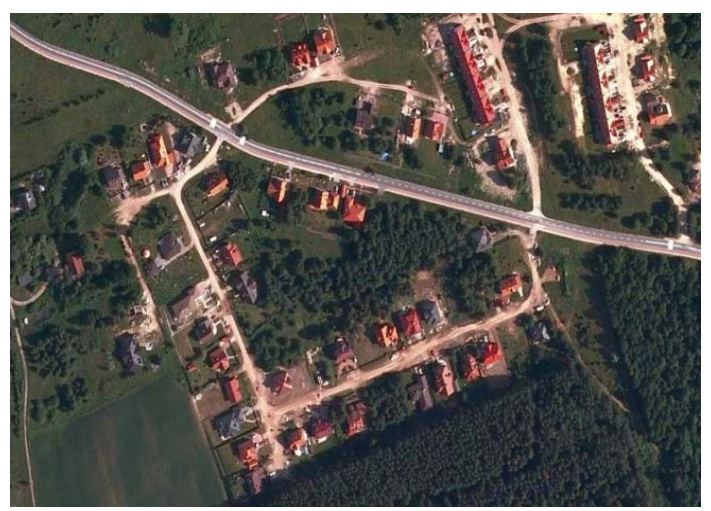

Fig. 8. Examples of buildings in Dywity Commune (Różnowo).

Source:http:// mapy.geoportal.gov.pl/imap/?gpmap=gp0\&actions=acShowWgButtonPanel_kraj_OR TO. 
Changes in the architectural landscape refer to the development style of single-family houses which have been erected in the recent years in both communes. Newly-constructed buildings differ greatly in terms of their usable surface area, ranging from small single-family houses to large residences. Multi-colored facades of residential facilities and various types of roofs create an "architectural jumble" which does not create a uniform, harmonious composition of a well-managed suburban area. In effect, these areas lose their unique character, and increasingly resemble undisciplined urban housing estates (Fig. 9).

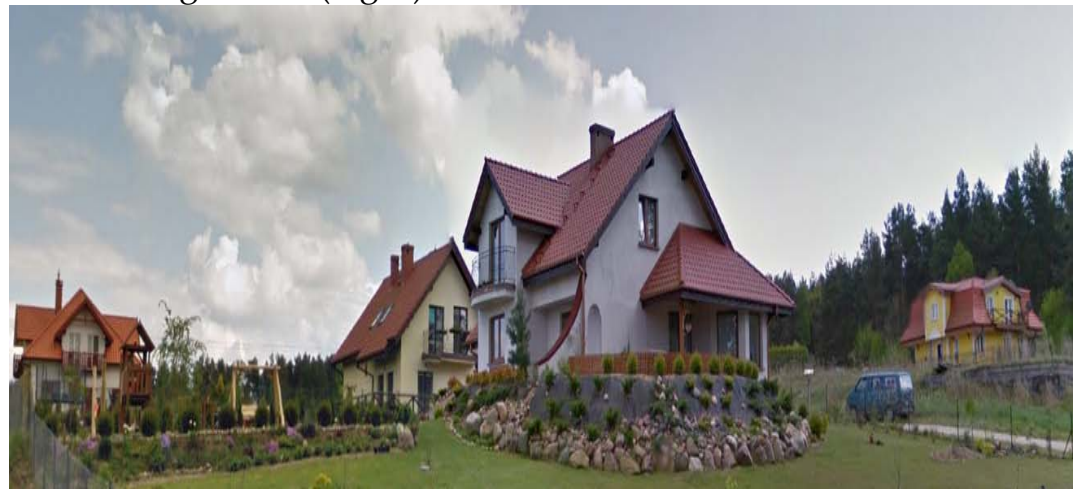

Fig. 9. Example of architectural development, Kieźliny district. Source: www.google.pl/maps.

Newly-erected single-family housing estates neighbor buildings which have existed in the area for decades and fulfilled residential functions. Examples are provided by rural settlements closely bound to the rural landscape (Fig. 10).

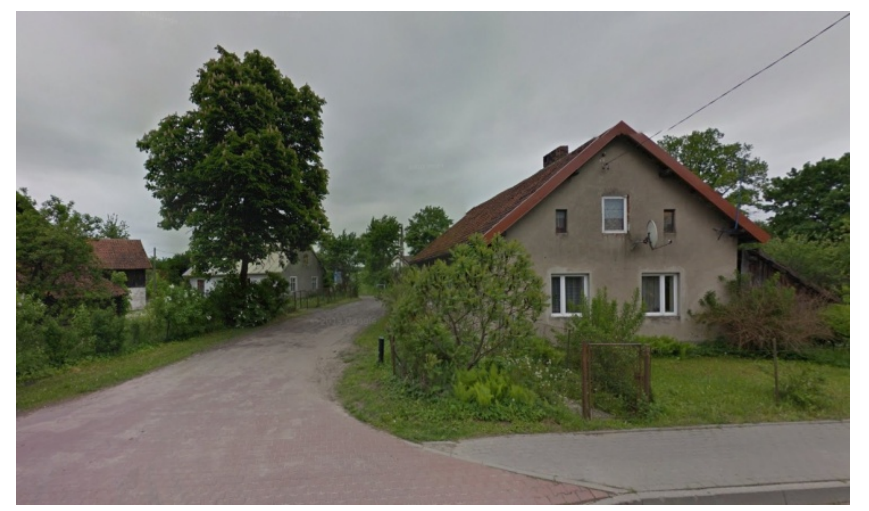

Fig. 10. Settlement development, Spręcowo district. Source: www.google.pl/maps.

\section{Conclusions}

Today's suburban villages are rarely associated with backwardness; more and more often, they take over functions that are characteristic of urban space. Areas of suburban communes, especially in the vicinity of large cities, become the destination of internal migration. In effect, the residential function develops dynamically in such areas. Any changes in the use of space and introduction of new elements to the existing landscape require a well-considered spatial policy pursued by the local authorities. The core of activities in this respect is the ability to make decisions that are justified by economic calculations, simultaneous preservation of spatial order (including landscape values), and ensuring proper protection of the natural environment. However, decisions of commune authorities are often triggered mainly by economic motives - being guided by the desire to procure new residents and tax-payers, the authorities focus on the development of the residential function. On the other hand, decisions of new residents with respect to the style and type of development significantly contribute to shaping the changes taking place in the landscape, and often lead to the destruction of spatial order. Investors primarily focus on their own style of development, without no regard to the architectural determinants contained in the local plan and referring to the location of buildings on a plot, the slope of roofs, the height of the development, the size of windows and their forms, the materials, the color of facades, etc. Striving to be distinguished by the form of the development, the individual character and the innovative approach to architecture, investors often erect buildings that 
clash with the existing development. Uncontrolled investment freedom, especially in areas with valuable features of the natural and cultural landscape, leads to irreversible effects in the spatial order and landscape. This situation is aggravated by the absence of a consistent control system of erected buildings and local development. Analysis of the selected communes of Dywity and Barczewo adjoining the city of Olsztyn indicates great spatial and landscape changes. Changes in the spatial development of such areas are often made in a random, chaotic and accidental manner. Uncoordinated transformations constitute a threat to the broadly-understood spatial order and cause irreversible changes in the cultural landscape.

\section{References}

EUROPEJSKA KONWENCJA KRAJOBRAZOWA dnia 20 października 2000 r., Florencja (EuROPEAN LANDSCAPE CONVENTION held 20 October 2000, Florence).

GoRdON P., RichaRdSON H.W., 1997, Alternative Views of Sprawl: Point; are Compact Cities a Desirable Planning Goal? Journal of the American planning Association, 63, pp. 107-126.

KoOmen E., DeKKers J.E.C., VAN DiJK T., 2007, Open Space Preservation in the Netherlands: Planning, Practice and Prospects, Land Use Policy 25, pp. 361-377.

Nelson A.C., 1999, Comparing States with and without Growth Management: Analysis based on Indicators with policy implications, Land Use Policy, 16, pp. 121-127.

MCDONAGH, 2007, Rural development., Understanding contemporary Ireland, pp. 88-99 in B. Bartley and R. Kitchin eds. London: Pluto Press.

Ustawa $z$ dnia 24 kwietnia 2015 r. o zmianie niektórych ustaw w zwiazku ze wzmocnieniem narzędzi ochrony krajobrazu, Dz.U. z 2015 r. poz. 774, 1688, (The Act of 24 April 2015, amending certain acts in connection with the strengthening of the tools of landscape protection, Journal of Laws, 2015, item $774,1688)$.

Ustawa z dnia 27 marca 2003 roku o planowaniu i zagospodarowaniu przestrzennym, Dz. U. z 2015 r. poz. 199, 443, 774, 1265, 1434, 1713, 1777, 1830, 1890, (The Act of 27 March 2003 on Spatial Planning and Development, Journal of Laws, 2015, item 199, 443, 774, 1265, 1434, 1713, 1777, 1830, 1890).

Ustawa z dnia 27 kwietnia 2001 roku Prawo ochrony środowiska, Dz. U. z 2013 r., poz. 1232, (The Act of 27 April 2001 Environmental Protection Law, Journal of Laws, 2013, item 1232).

Ustawa z dnia 23 lipca 2003 r o ochronie zabytków i opiece nad zabytkami, Dz. U. 2014r. poz. 1446, z 2015 r. poz. 397, 774., (The Act of 23 July 2003 on the protection of monuments and care of monuments, Journal of Laws, 2014, item 1446; Journal of Laws, 2015, item 397,774).

Ustawa z dnia 16 kwietnia 2004 r. o ochronie przyrody (Dz. U. z 2013 r., 627, z późn. zm., (Act of 16 April 2004, Nature Conservation, Journal of Laws, 2013, item 627, as amended).

Strategia rozwoju Gminy Dywity do 2020 r., http://barczewo.bip.net.pl/?c=87, (Strategy of development of the Municipality Dywity 2020).

Strategia rozwoju gminy Barczewo na lata 2015-2025, (Barczewo Commune development strategy for the years 2015-2025).

SOBOTKA S., 2014, Analiza obowiazujących planów zagospodarowania przestrzennego w strefie podmiejskiej Olsztyna, (Analysis of the Current Development Plans in the Suburban Area of Olsztyn) [in Polish] Acta Sci.Pol., Administratio Locorum 13(3)2014, str. 79-107. (Acta Sci.Pol., Administratio Locorum 13(3)2014, pp. 79-107).

WOLNY A., ŹRÓBEK R., 2012, Proces przekształcenia przestrzeni na obszarach o największej aktywności na rynku nieruchomości (The Process of Changing over Areas of Greatest Activity in the Real Estate Market) [in Polish] Studia i Materiały TNN, vol. $20 \mathrm{nr}$ 2, Olsztyn, (Studies and Materials of Real Estate Scientific Society, Vol. 20, No. 2, Olsztyn).

ZYSK E., 2013, Funkcja mieszkaniowa na obszarach wiejskich na przyktadzie gminy Stawiguda - aspekty społeczne i rynku nieruchomości (Residential Function in Rural Areas on the Example of Stawiguda Commune - Social and Real Estate Market Aspects) [in Polish], Planowanie rozwoju przestrzeni wiejskiej pod red. K. Kurowskiej (Planning the Development of Rural Space, ed. K. Kurkowska) Urząd Marszałkowski Województwa Warmińsko-Mazurskiego, Olsztyn (Marshal's Office of Warmia and Mazury, Olsztyn).

ZYSK E., 2014, Zrównoważony rozwój funkcji mieszkaniowej na obszarach wiejskich w strefie oddziaływania miasta, Analiza rynku i zarządzenie nieruchomościami (Sustainable Development of the Residential Function in Rural Areas in the Impact Zone of the City, Market Analysis and Real Estate Management) [in Polish], TNN, Olsztyn, str.101-116, (Real Estate Scientific Society, Olsztyn, pp. 101-116). 
ŹRÓBEK-RÓŻAŃSKA A., ZYSK E., 2015, Czy rozlewające się miasto odmładza podmiejską wieś? Studium podolsztyńskich gmin wiejskich (Does Urban Sprawl Rejuvenate Polish Villages? Study of Selected Rural Areas within Olsztyn Poviat) [in Polish] Wieś i Rolnictwo, nr 4 (169). (Village and Agriculture, No. 4 (169)).

Websites: (Real estate turnover in 2013, CSO) http:/ / stat.gov.pl/obszary-tematyczne/infrastrukturakomunalna-nieruchomosci/nieruchomosci-budynki-infrastruktura-komunalna/obrotnieruchomosciami-w-2013-r,4,11.html, accessed 30.12.2015 r.

www.stat.gov.pl, accessed 15.01.2016 r.

www.google.pl/maps, accessed 20.01.2016 r.

http:/ / mapy.geoportal.gov.pl, accessed 09.02.2016 r.

http:/ / barczewo.e-mapa.net, accessed 09.02.2016 r.

http:/ / dywity.e-mapa.net, accessed 09.02.2016 r.

http:/ / stat.gov.pl/vademecum/vademecum_warminskomazurskie/portrety_gmin/olsztynski/dywi ty.pdf, accessed 09.02.2016 r.

http://stat.gov.pl/vademecum/vademecum_warminskomazurskie/portrety_gmin/olsztynski/barcz ewo.pdf, accessed 09.02.2016 r. 